Tarbawy : Jurnal Pendidikan Islam

ISSN : 2407-4462 (Cetak), 2614-5812 (Elektronik)

Vol. 8, No. 1, 201x, Hal. 26-31

DOI: https://doi.org/ 10.32923/tarbawy.v8i1.1162

\title{
Konsep Pengembangan Kebiasaan Belajar Di Era Industri 4.0
}

\author{
Sakwa $^{1}$ \\ ${ }^{1}$ Pascasarjana UIN Sunan Kalijaga Yogyakarta
}

\section{Info Artikel :}

Diterima 3 januari 2021

Direvisi 20 februari 2021

Dipublikasikan 30 April 2021

\section{Kata Kunci:}

Bimbingan dan Konseling, Pembelajaran

Kebiasaan Belajar

Key Word:

Guidance and Counseling

Learning

Study habits

\begin{abstract}
ABSTRAK
Sebagai seorang guru bimbingan dan konseling tentunya mempunyai tugas membantu siswa mengatasi permasalahan tersebut dengan cara mengidentifikasi permasalahan belajar yang dialami siswa, menganalisis permasalahan tersebut secara tepat, menawarkan solusi atau solusi gaya belajar kepada siswa dalam menyelesaikan permasalahan belajar tersebut. Maksudnya agar siswa mampu mandiri dalam belajar. Hasil penelitian yang dilakukan peneliti dengan menggunakan angket DCM (Checklist of Problems) kepada 31 siswa kelas X IIK 2 di MAN 3 Bantul mendapatkan masalah tertinggi adalah masalah kebiasaan belajar. Pada aspek masalah kebiasaan belajar, item tertinggi yang menjadi masalah adalah waktu belajar yang tidak teratur, jika belajar sering mengantuk, belajar hanya pada malam hari, belajar ketika ada ulangan, dan sering merasa malas untuk belajar. Guru BK perlu membuat deskripsi kebutuhan apa saja yang diberikan kepada siswa, bagaimana tujuannya, alternatif pelayanan dan evaluasi seperti apa yang akan diberikan kepada siswa. Berdasarkan hasil penelitian yang telah dipaparkan diketahui bahwa siswa membutuhkan bantuan memberikan layanan bimbingan belajar yang efektif yang dapat mempengaruhi kebiasaan belajar siswa kelas X IIK.
\end{abstract}

Kata Kunci: Bimbingan dan Konseling, Pembelajaran, dan Kebiasaan Belajar

\begin{abstract}
As a guidance and counseling teacher, of course, has the task of helping students overcome these problems by identifying learning problems experienced by students, analyzing these problems appropriately, offering learning style solutions or solutions to students solving these learning problems. The point is that students are able to be independent in learning. The results of research conducted by researchers using the DCM questionnaire (Checklist of Problems) to 31 students of class X IIK 2 in MAN 3 Bantul get the highest problem is the problem of study habits. In the aspect of the problem of study habits, the highest item that becomes a problem is irregular learning time, if learning is often sleepy, studying only at night, studying when there are tests, and often feeling lazy to learn. Bk teachers need to make a description of what needs are given to students, how their goals, alternative service and what kind of evaluation to be given to students. Based on the results of the study it has been presented that it is known that students need help providing effective tutoring services that can affect the learning habits of students of class X IIK.
\end{abstract}

Keywords: Guidance and counseling, Learning, and Study habits

\section{Koresponden:}

Sakwa

Email: Santrimendunia12@gmail.com

\section{Pendahuluan}

Perkembangan teknologi yang semakin canggih menjadi salah satu faktor inovasi pembelajaran di sekolah harus ditingkatkan. Setiap siswa tentu pernah memiliki masalah dalam sistem pembelajaran di sekolah. Sebagai guru bimbingan dan konseling tentunya memiliki tugas membantu siswanya memiliki perkembangan belajar, prestasi akademik lebih baik yang mencangkup: mampu mengatasi kesulitan 
belajar, masalah belajar, memiliki motivasi belajar dan mengembangkan ketrampilan yang mendukung sehingga mencapai prestasi akademik secara maksimal.

Masalah yang sering dialami siswa beberapa disebutkan karena kurangnya pengetahuan umum, kesulitan menentukan pertanyaan, ketidakmampuan mengikuti proses belajar, mengolah informasi, dan kesulitan mengevaluasi masalah sehingga berimbas pada kebiasaan belajar siswa yang buruk ${ }^{1}$. Selain masalah disebabkan dari siswa, guru BK sendiri pun memiliki masalah dalam metode pengajaran. Masih banyak guru BK yang memberikan layanan dengan metode ceramah, sehingga siswa merasa bosan, tidak berpikir kreatif, dan lebih banyak mengabaikan isi ceramah dari guru BK. Seorang guru BK tentunya perlu memiliki inovasi dalam pengajaran seperti menggunakan permainan, tanya jawab, dan bisa menggunakan kecanggihan teknologi ponsel siswa dalam layanan pembelajaran. Dengan sistem pembelajaran yang menggunakan banyak inovasi yang lebih kreatif tentu membuat daya pacu berpikir, keaktifan, imajinasi siswa menjadi lebih meningkat.

Pergeseran paradigma lainnya dalam hal pendekatan pembelajaran. Pada era pendidikan Islam tradisional, guru menjadi figur sentral dalam kegiatan pembelajaran. Ia merupakan sumber pengetahuan utama di dalam kelas, bahkan dapat dikatakan satu-satunya. Namun dalam konteks guru BKan Islam modern, hal demikian tidak berlaku lagi. Peran guru hari ini telah mengalami pergeseram, yakni sebagai fasilitator siswa. pembelajaran tidak lagi berpusat pada guru (teacher centered), namun lebih berpusat pada siswa (student centered) $)^{2}$.

Tulisan ini berusaha memberikan pemikiran konsep pengembangan bimbingan \& konseling di era industri 4.0, supaya bisa dijadikan acuan bagi yang memerlukan. Tulisan ini bertujuan untuk menemukan konsep bimbingan dan konseling belajar yang dimungkinkan dapat menjawab tantangan di era industri 4.0. dengan menggunakan cara berpikir kritis dan analitis, mengacu pada beberapa pemikiran para pakar, tulisan ini diharapkan mencapai tujuan. Secara berturut-turut tulisan ini mengungkap hakikat bimbingan konseling belajar, diikuti cara mengembangkan konsep bimbingan konseling guna menjawab tantangan di era industri 4.0, dan diakhiri dengan desain penanganan masalah tersebut.

Bimbingan akademik ialah bimbingan dalam hal menemukan cara belajar yang tepat, dalam memilih progam studi yang sesuai, dan dalam mengatasi kesukaran yang timbul berkaitan dengan tuntutantuntutan belajar disuatu institusi pendidikan ${ }^{3}$. Sebagai siswa tentu banyak waktu yang ia habiskan belajar di sekolah. Mata pelajaran tertentu, sistem pembelejaran, atau gaya belajar siswa bisa saja menjadi salah satu faktor penghambat siswa mengalami kesulitan dalam menerima pelajaran di sekolah.

Tujuan bimbingan belajar adalah membantu siswa agar mencapai perkembangan yang optimal; sehinga tidak menghambat perkembangan belajar siswa ${ }^{4}$. Sebagai guru bimbingan dan konseling tentunya memiliki tugas membantu siswa mengatasi permasalahan tersebut dengan mengidentifikasi masalah belajar apa yang dialami siswa, menganalisis masalah tersebut secara tepat, menawarkan solusi gaya belajar atau jalan keluar siswa mengatasi masalah belajar tersebut. Poinnya, siswa mampu mandiri dalam belajar.

\footnotetext{
${ }^{1}$ Ignatius Gemilau Ragil Prasetya; Rachmat Djati Winarno, Praharesti Eriany, “Bimbingan Belajar Efektif Untuk Meningkatkan Kebiasaan Belajar Pada Siswa Kelas VII" (n.d.): 1.

2 Sigit Priatmoko, “Memperkuat Eksistensi Guru BKan Islam Di Era 4.0," TA’LIM: Jurnal Studi Guru BKan Islam 1. No 2. Juli. 2018 (2018): 3.

${ }^{3}$ WS Winkel \& M M Sri Hatuti, Bimbingan Dan Konseling Di Insitusi Guru BKan (Yogyakarta: Media Abadi, 2015), 115.

${ }^{4}$ Tohirin, Bimbingan Dan Konseling Di Sekolah Dan Madrasah (Berbasis Integrasi) (Jakarta: Rajawali press, 2013), 131.
} 
Beberapa bentuk layanan bimbingan belajar yang bisa diberikan kepada siswa di sekolah dan madrasah adalah pertama, orientasi kepada para siswa (khususnya siswa baru) tentang tujuan sekolah, isi kurikulum pembelajaran, struktur organisasi sekolah, cara belajar yang tepat, penyesuaian diri dengan corak di sekolah. Kedua, penyaluran kembali secara berkala tentang cara belajar yang tepat selama mengikuti pembelajaran di sekolah maupun di rumah baik secara individual maupun kelompok. Ketiga, bantuan dalam memilih jurusan atau progam studi yang sesuai, memilih kegiatan nonakademik yang menunjang usaha belajar dan memilih progam lanjutan untuk progam guru BKan yang lebih tinggi. Keempat, pengumpulan data siswa yang berkenaan dengan kemampuan intelektual, bakat khusus, arah minat, cita-cita hidup, pada jurusan tertentu. Kelima, bantuan mengatasi kesulitan belajar seperti kurang mampu menyusun jadwal belajar, kurang siap menghadapi ujian di sekolah, kurang mampu berkonsentrasi, kurang mampu menguasai cara belajar. Keenam, bantuan dalam hal membentuk kelompok belajar dan mengatur kegiatan beajar kelompok sipaya berjalan secara efektif dan efisien ${ }^{5}$.

Layanan bimbinngan belajar di sekolah salah satunya adalah pengenalan siswa yang mengalami masalah belajar ${ }^{6}$. Siswa di sekolah tentu memiliki beragam prestasi akademik, ada yang berhasil ada pula yang belum berhasil. Beberapa contoh siswa yang belum berhasil dalam pembelajaran seperti nilai rapor rendah, tidak lulus ujian nasional, tidak naik kelas. Siswa yang memiliki prestasi rendah seperti itu tentunya memiliki masalah belajar, yang biasanya dapat digolongkan menjadi

a. Keterlambatan akademik, yaitu keadaan siswa yang diperkirakan memiliki inteligensi yang cukup tinggi, tetapi tidak dapat memanfaatkannya secara optimal.

b. Ketercepatan dalam belajar, yaitu keadaan siswa yang memiliki bakat akademik cukup tinggi atau memiliki IQ 130 atau lebih, tetapi memerlukan tugas khusus untuk memenuhi kebutuhan dan kemampuan belajarnya yang amat tinggi.

c. Sangat lambat dalam belajar, yaitu keadaan siswa yang memiliki bakat akademik kurang memadai dan perlu dipertimbangkan untuk mendapat guru BKan atau pengajaran khusus.

d. Kurang motivasi dalam belajar, yaitu keadaan siswa yang kurang bersemangat dalam belajar, mereka seolah-olah tampak jera dan malas.

e. Bersikap dan berkebiasaan buruk dalam belajar, yaitu kondisi siswa yang kegiatan atau perbuatan belajarnya sehari-hari anatagonistik dengan yang seharusnya, seperti suka menunda-nunda tugas, mengulur-ulur waktu, membenci guru, tidak mau bertanya untuk hal-hal yang tidak diketahuinya dan sebagainya.

\section{Metode}

Jenis penelitian yang dipakai adalah penelitian kuantitatif. Penelitian ini dilakukan untuk mengetahui pengaruh pemanfaatan waktu dalam membentuk kebiasaan belajar,. Populasi dalam penelitian ini adalah seluruh siswa kelas X IIK MAN 3 Bantul sebanyak 82 siswa yang berasal dari 2 kelas, yang terdiri dari: kelas X IIK 1 sebanyak 40 siswa, kelas X IIK 2 sebanyak 42 siswa. Dalam penelitian ini teknik yang digunakan adalah simple random sampling. Simple random sampling adalah teknik pengambilan anggota sampel dari populasi dilakukan secara acak tanpa memperhatikan strata yang ada dalam populasi itu (Sugiyono, 2008). Dalam penentuan besarnya sampel menggunakan rumus Slovin. Dari hasil penghitungan rumus Slovin tersebut, jumlah sampel yang didapat adalah 49 siswa.

\section{Hasil dan Pembahasan}

Hasil penelitian yang dilakukan oleh peneliti kepada 49 siswa kelas X IIK di MAN 3 Bantul mendapatkan hasil masalah tertinggi adalah masalah kebiasaan belajar. Dalam aspek masalah kebiasaan

\footnotetext{
${ }^{5}$ Ibid., 131-132.

${ }^{6}$ Prayitno \& Anti, Erman, Dasar-Dasar Bimbingan Dan Konseling, Edisi Revisi. (Jakarta: Rineka Cipta, 2004), 279.

7 Ibid.
} 
belajar, item tertinggi yang menjadi masalah adalah waktu belajar tidak teratur, kalau belajar sering mengantuk, belajar hanya pada malam hari, belajar ketika ada ulangan, dan sering merasa malas belajar.

Bimbingan belajar yang dilaksanakan, lebih berfokus pada upaya umum membantu siswa dalam mengatasi hambatan dalam belajar. Pelaksanaan bimbingan belajar dengan tujuan untuk mencegah timbulnya masalah siswa dalam belajar, cara belajar siswa, motivasi siswa dalam belajar. Jumlah peserta bimbingan belajar terdiri dari 31 orang. Jenis tema membantu siswa dalam menumbuhkan sikap kebiasaan belajar yang baik, cara belajar efektif, cara mengatasi kesulitan belajar, cara mengembangkan susana belajar, cara, penggunaan sumber balajar. Dalam pelaksanaan bimbingan belajar, sebelum pemberian layanan/bimbingan guru bimbingan dan konseling melakukan need assessment.

Kebiasaan belajar adalah suatu cara atau metode belajar yang dilakukan seseorang secara berulangulang, sehingga menghasilkan keterampilan belajar yang menetap pada diri siswa dimana siswa akan terbiasa melakukannya tanpa ada paksaan ${ }^{8}$. Kebiasaan belajar pada dasarnya sesuatu yang dilakukan dengan cara yang sama dari waktu ke waktu, sehingga seseorang akan melakukannya secara otomatis. Kebiasaan belajar yang tersusun dan terencana dengan baik akan menghasilkan suatu dorongan bagi diri siswa untuk berprestasi dan bertanggung jawab dengan tugasnya.

Dengan demikian pembentukan kebiasaan belajar yang baik dapat dilakukan dengan cara belajar dan latihan dalam jangka waktu yang singkat tetapi dilakukan secara berulang-ulanng, belajar secara mandiri di luar jam pelajaran sekolah memperhatikan ketika guru menerangkan, dan berusaha menambah wawasan dan pengetahuan yang telah dimiliki. Pembentukan kebiasaan belajar yang baik perlu dikembangkan karena terbentuknya kebiasaan belajar yang baik dapat diperoleh prestasi belajar yang ingin dicapai. Bidang belajar yang harus diperhatikan oleh siswa menengah lanjutan atau siswa baru dalam membentuk kebiasaan belajar yang baik. Pengujian hipotesis 2 menunjukkan adanya pengaruh yang positif dan signifikan pada variabel prestasi belajar. Hasil ini menunjukkan bahwa penilaian yang baik mengenai lingkungan belajar yang sesuai dengan tingkat baik atau tidaknya kualitas prestasi belajar yang dilakukan siswa untuk tetap setia terhadap lingkungan belajar. Hasil ini menjelaskan bahwa hasil pengalaman siswa dalam belajar yang tepat membutuhkan lingkungan belajar yang baik pula. Apabila lingkungan belajar tidak mendukung, maka hasil dari belajar tentu kurang memuaskan. Untuk itu lingkungan belajar benar-benar dibutuhkan agar mendapatkan hasil prestasi yang memuaskan.

Bimbingan belajar yang dilaksanakan terdiri dari tiga tahapan yaitu tahap pembukaan, tahap kegiatan, tahap pengakhiran/penutup. Sedangkan pelaksanaan evaluasi berfokus pada evaluasi hasil meliputi evaluasi segera dan evaluasi jangka panjang. Kerja sama antara kepala sekolah, guru BK, guru mata pelajaran dan wali kelas menjadi faktor pendukung dalam pelaksanaan bimbingan, namun hambatan yang ditemui adalah dari segi waktu dimana waktu yang diberikan minim, beban tugas guru bimbingan dan konseling yang tidak ideal dan adanya pemahaman guru mata pelajaran dan wali kelas yang keliru terhadap tujuan atau fungsi layanan bimbingan dan konseling. Dalam pelaksanaan bimbingan belajar juga belum ada pengembangan teknik yang digunakan sehinggat efektivitas bimbingan tidak tercapai secara optimal.

Untuk mengembangkan konsep bimbigan dan konseling belajar di era industri 4.0, peneliti mengembangkan Expressive Art dalam Choice Theory. Siswa memiliki kebutuhan psikologis berupa cinta/rasa memiliki (Love/belonging), Kekuasaan (Power), Kesenangan (Fun), Kebebasan (Freedom), Mempertahankan hidup. Hakikat manusia, manusia menginginkan mendapat kebutuhan tercapai sehingga merasa memiliki identitas, melalui konsep 3R. Keadaan dimana individu dapat menerima kondisi yang dihadapinya, dicapai dengan menunjukkan total behavior (perilaku total), yakni melakukan sesuatu (doing), berfikir (thingking), merasa (feeling), dan menunjukkan respons fisiologis (physiology) secara bertanggungjawab (responsibility), sesuatu realita (reality), dan benar (right).

Materi pokok bimbingan konseling belajar antara lain adalah :

1. Pemantapan sikap dan kebiasaan belajar yang efektif dan efisien

\footnotetext{
${ }^{8}$ Mardiyatun Mugi Rahayu, “PENGARUH KEBIASAAN BELAJAR TERHADAP HASILBELAJAR MATEMATIKA SISWA KELAS VSD NEGERIDAERAH BINAANII KECAMATAN AJIBARANG BANYUMAS," FIP UNES (2015).
} 
2. Pengembangan kemampuan belajar dan menulis secara cepat

3. Pemantapan penguasaan materi pembelajaran

4. Pemahaman tentang pemanfaatan hasil teknologi bagi pengembangan

5. Pemanfaatan kondisi fisik, sosial dan budaya bagi pengembangan pengetahuan

6. Pemahaman tentang pemanfaatan perpustakaan

7. Orientasi belajar di perguruan tinggi (jenjang pendidikan) lebih tinggi.

Berdasarkan hasil penelitian telah disajikan diketahui siswa membutuhkan bantuan pemberian layanan bimbingan belajar secara efektif yang dapat mempengaruhi kebiasaan belajar siswa kelas X IIK . Bimbingan belajar efektif merupakan bantuan yang diberikan kepada siswa supaya mereka mempunyai kebiasaan belajar yang baik. Bimbingan belajar efektif dimaksudkan untuk membentuk kebiasaan belajar sehingga individu dapat melakukan aktivitas belajar tanpa paksaan dari pihak luar, dengan kata lain belajar dengan kesadaran sendiri.

Dalam kegiatan sehari-hari ditemukan adanya kebiasaan belajar yang kurang baik. Kebiasaan tersebut antara lain berupa (1) belajar pada akhir semester; (2) belajar tidak teratur; (4) menyia-nyiakan kesempatan belajar; (5) bersekolah hanya untuk bergengsi; (6) datang terlambat bergaya pemimpin; (7) bergaya jantan seperti merokok; (8) sok menggurui teman; dan (8) bergaya minta "belas kasihan" tanpa belajar9. Dari hal tersebut dapat diketahui bahwa siswa memiliki keiasaan belajar yang kurang baik sehingga memberi dampak pada prestasi mereka di sekolah. Sisa mengalami penurunan kualitas dari segi prestasi, sosial, dan mental.

Siswa memerlukan kunci baru untuk merubah kebiasaan belajar mereka. Di era industri 4.0 semua orang dituntut memiliki kelebihan dari orang lain, melihat semua orang sudah tergantikan oleh mesin. Para siswa inilah perlu membiasakan hal yang baik dan inovatif di semua bidang, termasuk dalam bidang belajar.

Kebiasaan belajar yang dapat memengaruhi hasil belajar meliputi: (1) pembuatan jadwal dan pelaksanaannya; (2) membaca dan membuat catatan; (3) mengulangi bahan pelajaran; (4) konsentrasi; dan (5) mengerjakan tugas ${ }^{10}$. Siswa perlu melatih kebiasaan belajar yang baik. Sebagaimana nantinya akan membuat dampak yang bagus dalam prestasinya, mentalnya, maupun psikologinya.

Siswa yang memiliki kebiasaan belajar baik tentunya akan memiliki dampak yang mampu dirasakan dan dilihat oleh diri sendiri maupun orang lain. Hasil belajar yaitu perubahan-perubahan yang terjadi pada diri siswa, baik yang menyangkut aspek kognitif, afektif, dan psikomotor sebagai hasil dari kegiatan belajar ${ }^{11}$. Dalam kegiatan pembelajaran atau kegiatan instruksional, biasanya guru menetapkan tujuan belajar. Siswa yang berhasil dalam belajar adalah siswa yang berhasil mencapai tujuan-tujuan instruksional.Berdasarkan pendapat para ahli tersebut, dapat disimpulkan bahwa hasil belajar adalah perubahan-perubahan seseorang yang berupa tingkah laku dimana perubahan itu terjadi secara bertahap dan berdasarkan akibat pengalaman dari kegiatan belajarnya.

Hasil penelitian ini didukung oleh pendapat Archer (1989), kebiasaan belajar siswa tidaklah bersifat bawaan lahir melainkan didapat melalui latihan yang konsisten dan sengaja dilakukan melalui pembiasan.Kizlik(2010), menyatakan bahwa kebiasaan belajar dapat ditingkatkan melalui bimbingan belajar dari guru.

\section{Kesimpulan}

\footnotetext{
${ }^{9}$ Dimyati dan Mujiono, Belajar Dan Pembelajaran (Jakarta: Rineka Cipta, 2009).

${ }^{10}$ Slameto, Belajar Dan Faktor-Faktor Yang Mempengaruhinya (Jakarta: Rineka Cipta, 2013).

${ }^{11}$ Susanto, Ahmad, Pembelajaran Di Sekolah Dasar (Jakarta: Kencana Prenada Media Group, 2013).
} 
Bedasarkan hasil peneliitian di MAN 3 BANTUL menunjukkan hasil bahwa siswa membutuhkan penanganan lebih terkait bidang belajar, sebagai guru bk perlu memberikan materi yang sesuai dengan kebutuhan siswa, menganalisis masalah apa yang terjadi dengan siswa, dan memberikan layanan yang komprehensif. Dampak yang akan terjadi jika kebiasaan belajar siswa rendah di era revolusi industri 4.0 ini adalah kurangya kemampuan bersaing siswa. kemampuan bersosialisasi siswa juga akan terbatas. Jika hal itu terjadi tentu mereka akan kehilangan keberanian dan kepercayaan diri dalam menghadapi tantangan yang ada pada era sekarang dan pada era yang akan datang. Oleh karena itu kebiasaan belajar perlu ditumbuhkan sejak dini agar kelak para siswa di era industri 4.0 memiliki keunggulan dan siap bersaing dengan tantangan yang ada.

\section{Referensi}

Dimyati dan Mujiono. Belajar Dan Pembelajaran. Jakarta: Rineka Cipta, 2009.

Ignatius Gemilau Ragil Prasetya; Rachmat Djati Winarno, Praharesti Eriany. "Bimbingan Belajar Efektif Untuk Meningkatkan Kebiasaan Belajar Pada Siswa Kelas VII” (n.d.).

Mardiyatun Mugi Rahayu. "PENGARUH KEBIASAAN BELAJAR TERHADAP HASILBELAJAR MATEMATIKA SISWA KELAS VSD NEGERIDAERAH BINAANII KECAMATAN AJIBARANG BANYUMAS." FIP UNES (2015).

Prayitno \& Anti, Erman. Dasar-Dasar Bimbingan Dan Konseling. Edisi Revisi. Jakarta: Rineka Cipta, 2004.

Sigit Priatmoko. "Memperkuat Eksistensi Pendidikan Islam Di Era 4.0." TA'LIM: Jurnal Studi Pendidikan Islam 1. No 2. Juli. 2018 (2018).

Slameto. Belajar Dan Faktor-Faktor Yang Mempengaruhinya. Jakarta: Rineka Cipta, 2013.

Susanto, Ahmad. Pembelajaran Di Sekolah Dasar. Jakarta: Kencana Prenada Media Group, 2013.

Tohirin. Bimbingan Dan Konseling Di Sekolah Dan Madrasah (Berbasis Integrasi). Jakarta: Rajawali press, 2013.

WS Winkel \& M M Sri Hatuti. Bimbingan Dan Konseling Di Insitusi Pendidikan. Yogyakarta: Media Abadi, 2015. 